\title{
Video Animasi Matematika Dengan Pendekatan Kontekstual Untuk Meningkatkan Pemahaman Konsep Matematika
}

\section{Hardi Apriadi}

Pendidikan Matematika, Univertsitas Jambi, Muaro Jambi, Indonesia; apriadihardi18@gmail.com

Info Artikel: Dikirim: 16 Juni 2020 ; Direvisi: 17 September 2020; Diterima: 2 Maret 2021 Cara sitasi: Apriadi, H. (2021). Pengembangan Video Animasi Matematika Dengan Pendekatan Kontekstual Untuk Meningkatkan Pemahaman Konsep Matematika. JNPM (Jurnal Nasional Pendidikan Matematika) 5(1), 173-187.

\begin{abstract}
Abstrak. Kemajuan teknologi telah mengubah dunia pendidikan dalam mengemas bahan belajar untuk siswa agar lebih efektif, praktis, dan efisien. Bahan belajar yang dikemas dengan format video animasi akan lebih praktis dan membuat matematika yang bersifat abstrak akan dapat digambarkan dengan baik. Penelitian ini bertujuan untuk mengembangkan video animasi matematika dengan pendekatan kontekstual untuk meningkatkan pemahaman konsep matematika. Penelitian ini menggunakan jenis penelitian Research and Development (R\&D). Model pengembangan yang digunakan dalam penelitian ini adalah model ADDIE. Subjek penelitian adalah siswa kelas $X$ jenjang SMK. Teknik pengumpulan data yang digunakan adalah observasi, tes, dan wawancara. Hasil dari penelitian ini adalah sebuah prototipe media pembelajaran dalam bentuk video animasi matematika dengan pendekatan kontekstual pada materi perbandingan trigonometri yang dikemas dalam sebuah aplikasi android yang telah melalui validasi media dan materi pembelajaran oleh ahli. Temuan ujicoba menunjukkan sebagian siswa mendapat hasil tes diatas kriteria ketuntasan minimal (KKM) dan persepsi siswa terhadap produk menunjukkan layak untuk digunakan.
\end{abstract}

Kata Kunci: Media Pembelajaran, Video Animasi, Kontekstual, Pemahaman Konsep Matematika.

\begin{abstract}
Advances in technology have changed the world of education in packaging learning materials for students to be more effective, practical, and efficient. Learning materials that are packaged in an animated video format will be more practical and make abstract mathematics well illustrated. This study aims to develop mathematical animation videos with contextual approaches to improve the understanding of mathematical concepts. This research uses the type of Research and Development $(R \mathcal{E} D)$ research. The development model used in this study is the ADDIE model. The subjects of the study were students of $10^{\text {th }}$ grade at Vocational School. Data collection techniques used were observation, tests, and interviews. The results of this research is a prototype of instructional media in the form of a mathematics animation video with a contextual approach to the trigonometric comparison that is packaged in an android application that has been through media learning and material learning validations by experts. The test findings show that some students get test results above the minimum completeness criteria (KKM) and students' perceptions of the product show that it is feasible to use. Keywords: Instructional Media, Video Animation, Contextual, Understanding of Mathematical Concepts.
\end{abstract}




\section{Pendahuluan}

Di era globalisasi sekarang, telah membawa perubahan yang sangat besar diberbagai bidang kehidupan seperti transportasi, perdagangan, pemerintahan hingga dunia pendidikan. Salah satu dampak baik bagi pendidikan di Indonesia adalah siswa akan lebih mudah mendapatkan informasi dengan cepat hanya dengan telepon genggam mereka. Sebuah analisis menunjukkan bahwa teknologi dapat meningkatkan pembelajaran (Schmid, Bernard, Borokhovski, Tamim, Abrami, Surkes \& Woods, 2014). Survei yang dilakukan APJII (Asosiasi Penyelenggara Jasa Internet Indonesia) tahun 2017 menunjukan penetrasi pengguna internet terbesar adalah dari kalangan usia 13-18 tahun dengan 75,5\% (APJII, 2017). Data tersebut menunjukkan bahwa usia sekolah merupakan usia yang paling sering menggunakan internet. Lebih lanjut APJII menunjukkan pemanfaatan internet untuk edukasi adalah membaca artikel $55,30 \%$, melihat video $49,67 \%$, share artikel/video edukasi $21,73 \%$ dan kursus online $17,85 \%$. Video menjadi alat memperoleh informasi pilihan kedua setelah artikel.

Pembelajaran berbasis video telah lama digunakan untuk membantu pembelajaran di dalam kelas bahkan sejak Perang Dunia II (Yousef, Chatti, \& Schroeder, 2014). Pada beberapa penelitian menunjukkan penggunaan video pada pembelajaran dapat menjadi alat pendidikan yang sangat efektif (Brame, 2016). Contohnya pelajaran biologi, video memiliki nilai khusus karena siswa dapat merasa lebih menarik (Stockwell, B. R., Stockwell, M. S., Cennamo \& Jiang, 2015). Tapi, hanya 5 dari 10 orang yang memanfaatkan video sebagai edukasi di internet khususnya di Indonesia (APJII, 2017). Sehingga menyebabkan video tidak berkontribusi banyak untuk meningkatkan performa siswa. Menyediakan video edukasi yang menarik agar dapat menarik perhatian siswa menjadi tantangan tersendiri, karena terkadang siswa melewatkan informasi penting yang ada pada video (Guo, Kim, \& Rubin, 2014). Karena video sangat cocok untuk menjelaskan fenomena yang abstrak atau sulit untuk divisualisasikan yang menjadi sifat dari pelajaranpelajaran sekolah khususnya pelajaran sains (Dash, Kamath, Rao, Prakash, \& Mishra, 2016).

Matematika yang bersifat abstrak menjadi kesulitan tersendiri bagi siswa dalam mempelajarinya (Ferrari, 2003). Penggunaan animasi untuk pembelajaran matematika menjadi hal yang penting untuk memvisualisasikan hal-hal abstrak. Animasi adalah bentuk representasi dinamis yang menampilkan proses yang berubah seiring waktu (Amalia, 2017). Secara sederhana, animasi merupakan gambar yang tidak bergerak dibuat menjadi bergerak sehingga seperti hidup. Animasi membuat siswa 
lebih mudah untuk memahami konsep abstrak dan memastikan sebuah pembelajaran dapat mudah diingat (Baglama, Yucesoy, \& Yikmis, 2018). Animasi interaktif yang digunakan sebagai alat presentasi, lebih efektif untuk pemahaman konsep siswa dibandingkan dengan instruksi normal (Akpınar, 2014). Ide animasi untuk digunakan dalam pembelajaran adalah karena dapat mengatur dengan bebas pergerakkan pada tampilan sebuah gambar (Zahra, 2016). Animasi sebagai alat multimedia, merupakan sebuah sistem visualisasi yang paling baik (Xiao, 2013).

Matematika sering dianggap siswa sebagai sesuatu yang tidak berguna karena siswa mempelajari matematika sekolah sebagai jenis matematika yang terpisah dari matematika kehidupan nyata sehingga mengalami kesulitan dalam menghubungkannya satu sama lain (Yavuzmumcu, 2018). Seharusnya, pertanyaan matematika yang sulit jangan dijawab sulit juga, namun harus dijawab dengan sesederhana mungkin. Oleh karena itu, matematika harus dikemas sangat ringan, meskipun konten pembahasannya ada yang berat. Megan Roberts, seorang executive director of math for America(MFA) menjelaskan bahwa praktik matematika pada hal-hal sederhana seperti harga, kembalian belanja, panjang dan lebar suatu benda dapat mengurangi kecemasan siswa, hal ini sering disebut dengan pembelajaran kontekstual. Pembelajaran kontekstual (Contextual Teaching and Learning) adalah sebuah konsepsi belajar mengajar yang membantu guru menghubungkan materi pelajaran dengan dunia nyata, memotivasi siswa untuk membuat koneksi antara pengetahuan dan aplikasinya dalam kehidupan mereka, dan terlibat aktif dalam proses belajar mengajar (Hudson \& Whisler, 2007). Pendekatan Contextual Teaching and Learning (CTL) merupakan salah satu cara penyajian pelajaran materi dengan mengekspos siswa pada masalah yang harus dipecahkan atau diselesaikan untuk mencapai tujuan pendidikan yang terkait dengan kehidupan sehari-hari (Dewi \& Primayana, 2019). Prinsip dari pembelajaran dengan pendekatan kontekstual adalah memfasilitasi siswa untuk memahami materi pelajaran dan memperluas berpikir kreatif siswa sehingga siswa bisa menghubungkan antara pengetahuan dengan kehidupan nyata (Syamsuddin \& Istiyono, 2018). Pembelajaran dengan pendekatan kontekstual dapat mengaktifkan pengetahuan dan pengalaman siswa, bisa menjadi pembelajaran mandiri, mengembangkan kompetensi matematika siswa, dan memberikan pemahaman bahwa matematika dapat diterapkan dan berguna dalam kehidupan (Selvianiresa \& Prabawanto, 2017).

Faktanya, di Indonesia terdapat kesenjangan yang besar antara kemampuan matematika siswa dengan apa yang seharusnya mereka ketahui berdasarkan kurikulum pendidikan (Beatty, Berkhout, Bima, Coen, Pradhan \& 
Suryadarma, 2018). Pada riset PISA (Program for International Student Assesment) 2015 menempatkan Indonesia pada peringkat 62 dari 70 negara yang dievaluasi dalam bidang matematika, sains, dan membaca pada siswa berumur 15 tahun (OECD, 2019). Siswa hanya memiliki kemampuan prosedural tanpa tau hubungan-hubungan antara setiap materi matematika yang dipelajari sehingga seolah-olah materi matematika semuanya terpisah. Hal ini menyebabkan pemahaman konsep matematika menjadi rendah. Padahal, semua materi matematika terhubung satu sama lain yang membentuk sebuah konsep besar. Kemampuan matematika siswa yang lemah pada materi prasyarat merupakan faktor utama penentu rendahnya pemahaman konsep siswa (Acharya, 2017).

Pemahaman konsep merupakan kemampuan memahami konsep, operasi dan relasi matematika. Pemahaman konseptual mengacu pada kemampuan siswa memahami dan menguasai konsep melalui suatu fenomena, peristiwa, objek, atau kegiatan yang berhubungan dengan materi pelajaran (Artayasa, Susilo, Lestari, \& Indriwati, 2018). Siswa dengan pemahaman konseptual tahu lebih dari fakta dan metode yang terisolasi. Mereka memahami mengapa ide matematika itu penting dan jenis konteks yang berguna. Mereka telah mengatur pengetahuan mereka menjadi satu kesatuan yang koheren, yang memungkinkan mereka untuk mempelajari ide-ide baru dengan menghubungkan ide-ide itu dengan apa yang sudah mereka ketahui. Pemahaman konseptual juga mendukung retensi, karena fakta dan metode matematika dipelajari dengan pemahaman yang saling terhubung, sehingga pelajaran lebih mudah diingat dan digunakan, serta dapat direkonstruksi ketika dilupakan (Killpatrick, Swafford \& Findell, 2001). Pemahaman konsep matematika sangat penting dalam matematika, karena pemahaman konsep akan membantu dalam mengatasi masalah dalam matematika dan masalah diluar matematika (Saleh \& Yumiati, 2019).

Ketersediaan bahan belajar yang dapat menjelaskan hubungan-hubungan antar setiap materi matematika menjadi sangat penting saat ini. Dengan kurangnya jam pelajaran matematika di sekolah saat ini, bahan belajar yang lengkap, praktis, efektif, dan efisien dapat menjadi bahan belajar mandiri di rumah. Mengembangkan video dengan format animasi dengan pendekatan kontekstual sebagai upaya untuk menyediakan bahan belajar yang lengkap, praktis, efektif, dan efisien yang kemudian diharapkan dapat meningkatkan pemahaman konsep matematika. Untuk itu, penelitian ini bertujuan untuk mengembangkan video animasi matematika dengan pendekatan kontekstual untuk meningkatkan pemahaman konsep siswa. 


\section{Metode}

Jenis penelitian yang digunakan adalah penelitian $\mathrm{R} \& \mathrm{D}$ (Riset $\mathcal{E}$ Development). Model pengembangan yang digunakan dalam penelitian ini (Gambar 1) adalah model ADDIE, yaitu Analysis (analisis), Design (perencanaan), Development (pengembangan), Implementation (pelaksanaan) dan Evaluation (evaluasi) (Branch, 2009).

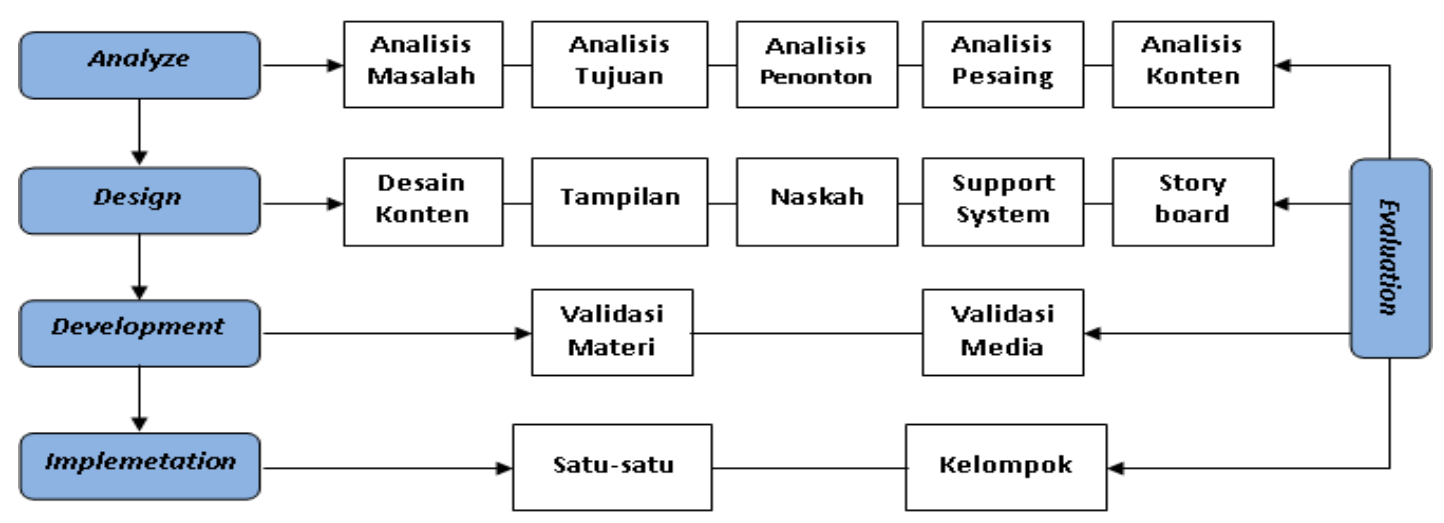

Gambar 1. Bagan Pengembangan Model ADDIE

Produk yang dikembangkan pada penelitian ini adalah video animasi matematika dengan pendekatan kontekstual pada materi perbandingan trigonometri yang didesain untuk meningkatkan pemahaman konsep matematika. Produk yang dikembangkan divalidasi oleh ahli dan praktisi sebelum diujicobakan kepada siswa (Rusdi, 2018). Validasi ahli yang dilakukan pada aspek media dan materi pembelajaran. Kemudian, validasi praktisi yang dilakukan oleh seorang guru mata pelajaran matematika.

Subjek uji coba pada penelitian ini adalah siswa kelas $X$ jenjang SMK yang terdiri dari 20 orang. Data yang dikumpulkan pada penelitian ini berupa saran dari validasi ahli dan praktisi, hasil tes siswa setelah uji coba produk, dan persepsi siswa terhadap produk yang diuji cobakan. Uji coba dilakukan dengan meminta siswa menginstal aplikasi pemutar video yang dikembangkan kemudian mempersilahkan siswa untuk menonton video animasi matematika dengan pendekatan kontekstual. Setelah itu, siswa diberikan instrumen penelitian.

Instrumen penelitian yang digunakan adalah angket terbuka untuk validasi, angket tertutup untuk persepsi siswa, dan tes untuk hasil belajar siswa. Angket terbuka adalah angket yang disusun sedemikian rupa sehingga responden bebas mengemukakan pendapat berupa saran dan komentarnya (Sugiyono, 2014). Butir-butir angket terbuka disusun sesuai dengan kriteria perangkat media pembelajaran yang berkualitas yaitu, kualitas isi dan tujuan, 
kualitas instruksional, dan kualitas teknis (Arsyad, 2017). Angket terbuka dalam penelitian ini terdiri dari 2 macam, yaitu angket validasi media pembelajaran dan angket validasi materi pembelajaran. Saran dan komentar dari tim validator merupakan data yang menyatakan produk yang dikembangkan layak untuk masuk ke tahap selanjutnya. Angket tertutup adalah pertanyaan atau pernyataan-pernyataan yang telah memiliki alternatif jawaban menggunakan skala penilaian yang dipilih oleh responden (Sugiyono, 2014). Skala penilaian yang digunakan adalah skala likert yang bertujuan untuk mengetahui sejauh mana pendidik dan peserta didik menerima atau menolak pernyataan yang diberikan. Tes untuk hasil belajar siswa berupa soal uraian yang sesuai dengan indikator pemahaman konsep materi perbandingan trigonometri. Setiap soal memiliki bobot yang berbeda dengan mempertimbangkan faktor yang berkaitan materi dan karakteristik soal itu sendiri, seperti ruang lingkup materi yang hendak dibuat soalnya, esensialitas dan tingkat kedalaman materi yang ditanyakan serta tingkat kesukaran soal.

\section{Hasil dan Pembahasan}

Hasil penelitian berupa video animasi dengan pendekatan kontekstual dan aplikasi pemutar video berbasis android. Video animasi dengan pendekatan kontekstual dibuat berdasarkan prinsip untuk memaksimalkan pembelajaran siswa dari konten video. Prinsip-prinsip yang dimaksud adalah cognitive load, student engagement, dan active learning (Brame, 2016). Tampilan video pada penelitian ini adalah infografis yang dianimasikan atau disebut juga motion graphic. Dikutip dari okdork.com, infografis merupakan format konten yang paling banyak dibagikan. Hal ini karena konten dengan format infografis akan membuat sebuah informasi lebih simple dan mudah untuk dimengerti sebab informasi disajikan dengan visual yang menarik. Durasi video animasi matematika dengan pendekatan kontekstual tidak lebih dari 6 menit. Siswa cenderung menonton video sampai habis sebuah video berdurasi maksimal 6 menit, dan ketika video lebih dari itu maka siswa banyak yang tidak menonton sampai habis (Guo, Kim, \& Rubin, 2014). 


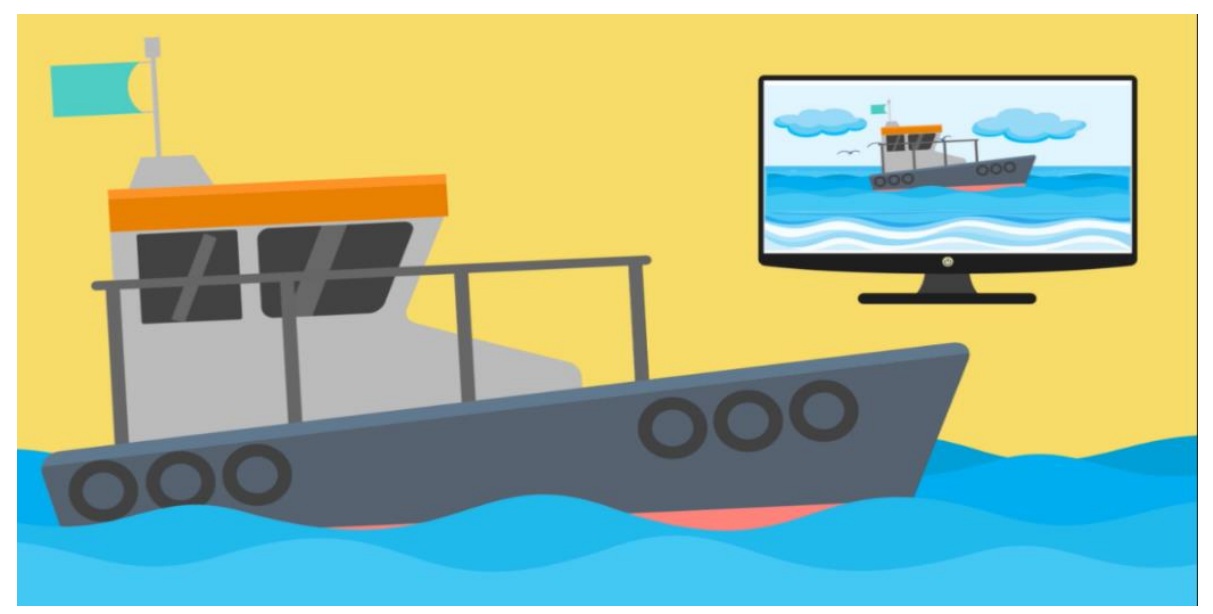

Gambar 2. Salah Satu Scene Dari Video Animasi Matematika

Gambar 2 menunjukkan penjelasan dari materi yang disajikan menggunakan narasi yang sesuai dengan tampilan. Siswa belajar lebih baik menggunakan animasi dan narasi daripada animasi dan teks on-screen (Mayer, 2009). Narasi menggunakan gaya bahasa "percakapan" yang bertujuan agar menciptakan rasa kebersamaan antara penonton dengan narrator. Penggunaan gaya bahasa percakapan daripada gaya bahasa formal saat pembelajaran yang menggunakan multimedia telah menunjukkan efek yang lebih baik pada proses belajar siswa (Brame, 2016).

Video animasi matematika dengan pendekatan kontekstual Video animasi matematika dengan pendekatan kontekstual yang dibuat untuk uji coba menampilkan materi perbandingan trigonometri. Materi trigonometri dipilih demi menyesuaikan jadwal uji coba yang sudah direncanakan. Berdasarkan konsep yang berhubungan dengan materi perbandingan trigonometri, video animasi dengan pendekatan kontekstual terdiri dari 3 video animasi, yaitu kesebangunan segitiga, definisi perbandingan trigonometri, dan sudut istimewa. Video animasi matematika tersebut dibuat berdasarkan urutan materi dari tingkat kesulitan rendah sampai tingkat kesulitan tinggi. Video animasi matematika sengaja dibuat terpisah-pisah agar siswa dapat memilih konsep apa yang ingin di pelajari sesuai dengan kemampuan masing-masing (Ibrahim, Antonenko, \& Wheeler, 2012).

Selain video animasi, juga dibuat aplikasi pemutar video yang berguna sebagai tempat "pengemasan" video animasi agar mudah ketika siswa ingin mengakses video animasi. Aplikasi pemutar video ini dibuat untuk memenuhi aspek dalam active learning, yaitu menggunakan fitur interaktif yang memberikan siswa kontrol pada video (Brame, 2016). Pembelajaran aktif akan memiliki banyak manfaat yang jelas daripada pembelajaran pasif yang 
hanya menggunakan metode ceramah (Freeman, Eddy, McDonough, Smith, Okoroafor, Jordt \& Wenderoth, 2014).

Pada video animasi matematika disisipkan pertanyaan interaktif untuk dijawab siswa. Sebuah penelitian yang membandingkan hasil tes siswa yang menonton video yang disisipkan pertanyaan dengan siswa yang menonton video tanpa sisipan pertanyaan, ditemukan bahwa siswa dengan sisipan video lebih baik pada hasil tesnya daripada siswa yang menonton tanpa sisipan pertanyaan (Szpunar, Khan, \& Schacter, 2013). Aplikasi pemutar video (Gambar 3) ini menyediakan tempat bagi siswa untuk menjawab pertanyaan yang muncul dari video lalu kemudian memeriksa jawaban tersebut benar atau salah. Animasi interaktif yang digunakan sebagai alat presentasi yang lebih efektif untuk pemahaman konsep siswa dibandingkan dengan instruksi normal (Akpinar, 2014). Aplikasi ini dibuat berbasis android karena OS ini yang paling banyak digunakan di siswa dan dibuat daring agar mengurangi penggunaan memori smartphone yang terlalu banyak. Schacter dan Szpunar (2015) Merekomendasikan video pembelajaran untuk dibagikan secara daring sebagai cara pembelajaran mandiri bagi siswa (Schacter \& Szpunar, 2015).

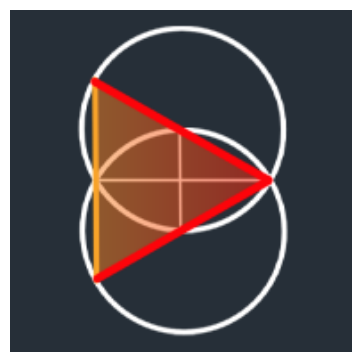

Gambar 3. Logo Aplikasi Pemutar Video

Pada validasi media dan materi pembelajaran dilakukan oleh dua orang ahli. Validator media pembelajaran dilakukan oleh ahli dengan bidang keahlian komputer sains. Validator materi pembelajaran dilakukan oleh ahli dengan bidang keahlian pendidikan matematika. Validasi dilakukan dengan validator memberikan penilaian pada angket terbuka mengenai video animasi matematika dengan pendekatan kontekstual. Berdasarkan penilaian para ahli didapat hasil penilaian video animasi matematika dengan pendekatan kontekstual yang dikembangkan dinyatakan valid dan layak digunakan dalam proses penelitian selanjutnya yaitu tahap uji coba dengan revisi berdasarkan saran dari ahli.

Media pembelajaran pada video animasi matematika yang dikembangkan ini divalidasi pada aspek teknis, yaitu keterbacaan, mudah digunakan, kualitas 
tampilan, kualitas pengelolaan program, kualitas pendokumentasian, prinsip multimedia, dan kualitas penanganan jawaban (Arsyad, 2017).

Beberapa catatan yang diberikan ahli media pembelajaran adalah sebagai berikut:

a) Volume musik backsound sebaiknya sedikit diperbesar.

b) Ketika transisi scene, musik backsound sebaiknya lebih dominan.

c) Perlu petunjuk berupa tanda garis atau tanda tanya pada scene kontekstual untuk pertanyaan bayangan anak.

d) Ukuran memori video sebaiknya lebih diperkecil tanpa mengurangi kualitas tampilan.

e) Ukuran memori alat pemutar video terlalu besar dan sebaiknya diperkecil agar bisa diinstal disemua smartphone.

Dari catatan yang diberikan tersebut selanjutnya peneliti memperbaiki produk sesuai dengan saran tersebut dengan menaikan volume musik backsound yang sebelumnya $10 \%$ menjadi $20 \%$, penambahan volume musik hanya sedikit mempertimbangkan bahwa siswa bisa belajar lebih baik saat kata-kata, gambar-gambar, atau suara-suara ekstra/tambahan dibuang daripada dimasukkan (Mayer, 2009). Memberikan petunjuk berupa garis dan tanda tanya pada adegan-adegan kontekstual karena upaya memenuhi prinsip signalling yaitu bahwa siswa belajar lebih baik jika lambang/tanda yang menyorot susunan materi esensial ditambahkan (Mayer, 2009). Memperkecil ukuran memori video dengan memperkecil resolusi yang sebelumnya HD (1280x720 pixel) menjadi VGA (840x480 pixel) dan tidak mengurangi kualitas tampilan karena ukuran layar yang beredar sekarang rata-rata 5 inci.

Pada validasi materi pembelajaran di dalam video animasi, yang menjadi pertimbangan dalam pengujian produk ini adalah ketepatan isi dan tujuan, kelengkapan isi materi, minat/perhatian, kesesuain dengan situasi siswa, memberikan kesempatan belajar, memberikan bantuan belajar, hubungan dengan program pembelajaran lainnya, kualitas tes dan penilaian, dampak bagi siswa, dan dampak bagi guru (Arsyad, 2017).

Materi pembelajaran disajikan dengan narasi karena siswa bisa belajar lebih baik dari animasi dan narasi daripada animasi dan teks on-scren (Mayer, 2009). Narasi yang didengarkan juga diiringi dengan music latar belakang yang tidak mengganggu narasi utama karena siswa bisa belajar lebih baik saat katakata, gambar-gambar, atau suara-suara ekstra/tambahan dibuang daripada dimasukkan (Mayer, 2009). Materi pembelajaran disusun untuk memfasilitasi 
pembelajaran aktif. Pembelajaran aktif mungkin dapat dilakukan dengan memberikan informasi melalui video, yang mana siswa dapat lebih mudah untuk belajar dan lebih mengingat daripada tulisan (Brame, 2016).

Validasi praktisi dilakukan kepada seorang guru mata pelajaran matematika. Guru yang menjadi validator adalah seorang guru mata pelajaran matematika yang bersertifikasi pendidik di salah satu SMA di Kota Jambi. Hasil validasi praktisi menyatakan produk layak untuk diuji cobakan.

Tabel 1. Hasil Tes Ujicoba Kelompok Kecil

\begin{tabular}{ccccccc}
\hline \multirow{2}{*}{ Siswa } & \multicolumn{5}{c}{ Skor Butir Soal } & \multirow{2}{*}{ STP } \\
\cline { 2 - 5 } S1 & 1 & 2 & 3 & 4 & 5 & \\
S2 & 10 & 10 & 16,7 & 0 & 0 & 36,7 \\
S3 & 10 & 10 & 16,7 & 0 & 0 & 36,7 \\
S4 & 10 & 10 & 25 & 10 & 25 & 80 \\
S5 & 3,3 & 10 & 25 & 10 & 16,7 & 65 \\
S6 & 10 & 10 & 25 & 30 & 25 & 100 \\
S7 & 10 & 10 & 25 & 10 & 25 & 80 \\
S8 & 10 & 10 & 25 & 10 & 16,7 & 71,7 \\
S9 & 10 & 10 & 25 & 10 & 16,7 & 71,7 \\
S10 & 10 & 10 & 25 & 10 & 16,7 & 71,7 \\
S11 & 3,3 & 10 & 25 & 10 & 16,7 & 65 \\
S12 & 10 & 10 & 16,7 & 20 & 16,7 & 73,3 \\
S13 & 10 & 10 & 16,7 & 0 & 0 & 36,7 \\
S14 & 10 & 10 & 16,7 & 0 & 0 & 36,7 \\
S15 & 3,3 & 10 & 25 & 10 & 16,7 & 65 \\
S16 & 10 & 10 & 25 & 10 & 25 & 80 \\
S17 & 10 & 10 & 16,7 & 0 & 0 & 36,7 \\
S18 & 10 & 10 & 25 & 10 & 25 & 80 \\
S19 & 10 & 10 & 25 & 10 & 16,7 & 71,7 \\
S20 & 10 & 10 & 25 & 10 & 25 & 80 \\
\hline
\end{tabular}

Pada tabel 1 dapat dilihat pada kolom STP (Skor Total Peserta) bahwa hasil tes 55\% siswa mendapatkan hasil diatas kriteria ketuntasan minimal (KKM). Kemudian ada beberapa siswa yang mendapatkan nilai yang sangat mendekati KKM karena hanya terdapat sedikit kesalahan dalam menghitung. Jika mengabaikan kesalahan tersebut maka 70\% siswa mencapai kompetensi dasar yang diharapkan.

Pada kolom Skor Butir Soal merupakan skor yang didapatkan siswa. Pedoman penskoran disusun dengan skala 0-30, setiap soal memiliki bobot yang berbeda, pembobotan soal dengan membandingkan terhadap soal lain dalam suatu perangkat tes yang sama. Skor akhir siswa ditetapkan dengan jalan 
membagi skor mentah yang diperoleh dengan skor mentah maksimumnya kemudian dikalikan dengan bobot soal tersebut. Total skor yang dapat dicapai adalah 100 (Panduan Penilaian Oleh Pendidik dan Satuan Pendidikan Untuk Sekolah Menengah Atas, 2017).

Soal tes yang diberikan terdiri dari 5 butir, dengan butir nomor 1, 2, dan 4 merupakan tes yang hanya menguji pemahaman konsep dalam video dan memiliki bobot nilai yang rendah, sedangkan nomor 3 dan 5 merupakan tes untuk menguji pemahaman konsep pada video yang membutuhkan pemahaman materi yang pernah dipelajari sebelumnya dan memiliki bobot nilai yang tinggi. Hasil tes menunjukkan semua siswa mampu menjawab soal tes nomor 1,2, dan 4 dengan benar, sedangkan nomor 3 dan 5 hanya beberapa siswa yang mampu menjawab dengan benar. Disimpulkan bahwa siswa rendah dalam materi yang dipelajari sebelumnya tapi sudah memahami konsep yang sedang diberikan.

Faktor yang mendukung pemahaman konsep adalah materi yang disajikan menggunakan narasi yang sesuai dengan tampilan karen siswa belajar lebih baik menggunakan animasi dan narasi daripada animasi dan teks on-screen (Mayer, 2009). Narasi menggunakan gaya bahasa "percakapan" yang bertujuan agar menciptakan rasa kebersamaan antara penonton dengan narrator. Penggunaan gaya bahasa percakapan daripada gaya bahasa formal saat pembelajaran yang menggunakan multimedia telah menunjukkan efek yang lebih baik pada proses belajar siswa (Brame, 2016). Tersedianya fitur pertanyaan interaktif pada video. Sebuah penelitian yang membandingkan hasil tes siswa yang menonton video yang disisipkan pertanyaan dengan siswa yang menonton video tanpa sisipan pertanyaan, ditemukan bahwa siswa dengan sisipan video lebih baik pada hasil tesnya daripada siswa yang menonton tanpa sisipan pertanyaan (Szpunar, Khan, \& Schacter, 2013).

Persentase hasil belajar yang pada angka 55\% juga dipengaruhi oleh faktor kemampuan materi yang dipelajari sebelumnya, untuk itu perlu dikembangkan lagi video animasi dengan pendekatan kontekstual ini agar mencakup seluruh materi matematika di sekolah.

Hasil uji coba produk kepada siswa dalam hal persepsi siswa menunjukkan persentase hasil angket 75,9\% yang berarti persepsi siswa sangat setuju terhadap produk yang diuji cobakan artinya produk layak untuk digunakan.

Tabel 2. Hasil Angket Persepsi Siswa 


\begin{tabular}{|c|c|c|c|c|c|c|c|c|c|c|c|c|c|}
\hline & 1 & 2 & 3 & 4 & 5 & 6 & 7 & 8 & 9 & 10 & 11 & 12 & \\
\hline S1 & 3 & 3 & 3 & 2 & 3 & 3 & 3 & 3 & 4 & 3 & 4 & 4 & 38 \\
\hline S2 & 4 & 2 & 4 & 2 & 4 & 3 & 3 & 3 & 4 & 3 & 4 & 4 & 40 \\
\hline S3 & 3 & 2 & 3 & 2 & 2 & 3 & 4 & 3 & 4 & 3 & 4 & 4 & 37 \\
\hline S4 & 3 & 4 & 3 & 4 & 3 & 3 & 3 & 3 & 3 & 3 & 3 & 4 & 39 \\
\hline S5 & 3 & 3 & 2 & 2 & 2 & 3 & 2 & 2 & 2 & 2 & 4 & 4 & 31 \\
\hline S6 & 4 & 3 & 3 & 3 & 3 & 3 & 3 & 2 & 3 & 3 & 3 & 3 & 36 \\
\hline S7 & 3 & 4 & 3 & 3 & 3 & 3 & 4 & 3 & 3 & 4 & 3 & 4 & 40 \\
\hline S8 & 4 & 3 & 3 & 3 & 3 & 4 & 3 & 3 & 3 & 3 & 4 & 4 & 40 \\
\hline S9 & 3 & 4 & 4 & 3 & 3 & 3 & 3 & 2 & 3 & 3 & 3 & 4 & 38 \\
\hline S10 & 4 & 3 & 3 & 3 & 3 & 3 & 3 & 3 & 3 & 3 & 3 & 3 & 37 \\
\hline $\mathrm{S} 11$ & 3 & 2 & 3 & 3 & 2 & 3 & 3 & 2 & 2 & 2 & 3 & 3 & 31 \\
\hline $\mathrm{S} 12$ & 3 & 3 & 3 & 3 & 3 & 3 & 3 & 3 & 3 & 3 & 3 & 3 & 36 \\
\hline S13 & 4 & 3 & 3 & 2 & 3 & 3 & 1 & 3 & 4 & 4 & 2 & 1 & 33 \\
\hline S14 & 3 & 3 & 3 & 3 & 3 & 3 & 3 & 3 & 3 & 3 & 3 & 3 & 36 \\
\hline S15 & 3 & 4 & 4 & 3 & 2 & 3 & 2 & 2 & 4 & 3 & 3 & 4 & 37 \\
\hline S16 & 3 & 3 & 3 & 2 & 4 & 4 & 3 & 3 & 4 & 4 & 3 & 3 & 39 \\
\hline $\mathrm{S} 17$ & 3 & 4 & 3 & 2 & 2 & 3 & 3 & 2 & 3 & 1 & 3 & 4 & 33 \\
\hline S18 & 3 & 3 & 3 & 3 & 4 & 3 & 3 & 4 & 3 & 3 & 4 & 3 & 39 \\
\hline S19 & 3 & 3 & 4 & 4 & 4 & 4 & 3 & 3 & 3 & 3 & 3 & 4 & 41 \\
\hline $\mathrm{S} 20$ & 3 & 2 & 2 & 2 & 2 & 3 & 2 & 2 & 2 & 2 & 3 & 3 & 28 \\
\hline Jumlah & 65 & 61 & 62 & 54 & 58 & 63 & 57 & 54 & 63 & 58 & 65 & 69 & 729 \\
\hline $\begin{array}{c}\text { Persentase } \\
(\%)\end{array}$ & 81,25 & 76,25 & 77,5 & 67,5 & 72,5 & 78,75 & 71,25 & 67,5 & 78,75 & 72,5 & 81,25 & 86,25 & 75,9 \\
\hline
\end{tabular}

Angket persepsi siswa terdiri dari 12 butir pertanyaan/pernyataan berupa kendala teknis, peningkatan minat belajar, mudah dipahami, dan membantu belajar mandiri. Persentase persepsi siswa terhadap produk yang tinggi menunjukkan bahwa produk tidak mengalami kendala teknis dalam penggunaan dan siswa lebih termotivasi ketika belajar menggunakan produk. Faktor yang mempengaruhinya adalah video animasi matematika dengan pendekatan kontekstual karena pembelajaran kontekstual membuat siswa mampu membuat hubungan dari isi materi-materi pelajaran dengan konteks yang ada dalam lingkungan mereka sehingga mendapati makna (Dewi \& Primayana, 2019). Setiap konsep yang membentuk pemahaman yang ingin dicapai dibuat dalam video yang terpisah, sengaja dibuat terpisah-pisah agar siswa dapat memilih konsep apa yang ingin di pelajari sesuai dengan kemampuan masing-masing (Ibrahim, Antonenko, \& Wheeler, 2012).

Selain faktor video animasi, faktor aplikasi pemutar video menjadi penting karena berguna sebagai tempat "pengemasan" video animasi agar mudah ketika siswa ingin mengakses video animasi kapanpun dan dimanapun. Schacter dan Szpunar (2015) Merekomendasikan video pembelajaran untuk 
dibagikan secara daring sebagai cara pembelajaran mandiri bagi siswa (Schacter \& Szpunar, 2015). Aplikasi pemutar video ini dibuat untuk memenuhi aspek dalam active learning, yaitu menggunakan fitur interaktif yang memberikan siswa kontrol pada video (Brame, 2016). Animasi interaktif yang digunakan sebagai alat presentasi yang lebih efektif untuk pemahaman konsep siswa dibandingkan dengan instruksi normal (Akpınar, 2014).

Dengan kata lain, desain media pembelajaran produk sudah siap untuk digunakan oleh siswa saat ini dan materi pembelajaran dalam produk perlu dikembangkan lagi untuk mencakup semua materi matematika sekolah.

\section{Simpulan}

Video animasi matematika dengan pendekatan kontekstual untuk meningkatkan pemahaman konsep matematika dikemas dalam sebuah aplikasi pemutar video berbasis android. Berdasarkan uji coba video animasi matematika dengan pendekatan kontekstual dapat meningkatkan pemahaman konsep matematika siswa dengan separuh hasil tes subjek uji coba dapat melampaui kriteria ketuntasan minimal (KKM), hasil ini turut dipengaruhi oleh kemampuan siswa dalam materi yang dipelajari sebelumnya. Persepsi subjek uji coba terhadap video animasi matematika dengan pendekatan kontekstual menunjukkan persepsi sangat setuju produk yang diuji coba layak untuk digunakan. Evaluasi lebih lanjut diperlukan untuk mengetahui dan memperbaiki beberapa kendala yang ditemui setelah produk dirilis.

\section{Daftar Pustaka}

Acharya, B. (2017). Factors Affecting Difficulties in Learning Mathematics by Mathematics Learners. International Journal of Elementary Education, 6(2), 8-15. https://doi.org/10.11648/j.ijeedu.20170602.11

Akpinar, E. (2014). The Use of Interactive Computer Animations Based on POE as a Presentation Tool in Primary Science Teaching. Journal of Science Education and Technology, 23(4), 527-537. https://doi.org/10.1007/s10956-013-9482-4

Amalia, R. (2017). Improving Listening And Speaking Skills By Using Animation Videos And Discussion Method. Pedagogy : Journal Of English Language Teaching, 2(1), 30-36.

APJII. (2017). Penetrasi dan Perilaku Pengguna Internet Indonesia. Asosiasi Penyelenggara Jasa Internet Indonesia.

Arsyad, A. (2017). Media Pembelajaran. Jakarta: Rajawali Pers.

Artayasa, I P. Susilo, H., Lestari, U., \& Indriwati, S. E. (2018). The Effect of Three Levels of Inquiry on the Improvement of Science Concept Understanding of Elementary School Teacher Candidates. International Journal of Instruction, 11(2), 235-248. https://doi.org/10.12973/iji.2018.11216a

Baglama, B., Yucesoy, Y., \& Yikmis, A. (2018). Using Animation as a Means of Enhancing Learning of Individuals with Special Needs. TEM Journal, 7(3), 670-677. https://doi.org/10.18421/TEM73-26 
Beatty, A., Berkhout, E., Bima, L., Coen, T., Pradhan, M., \& Suryadarma, D. (2018). Indonesia Got Schooled: 15 Years of Rising Enrolment and Flat Learning Profiles. RISE Working Paper Series. 18/026. https://doi.org/10.35489/BSG-RISE-WP 2018/026

Brame, C. J. (2016). Effective Educational Videos: Principles and Guidelines for Maximizing Student Learning from Video Content. CBE - Life Sciences Education, 15(4), 1-6. https://doi.org/10.1187/cbe.16-03-0125

Branch, R. (2009). Intructional Design: The ADDIE Approach. USA: Springer.

Dash, S., Kamath, U., Rao, G., Prakash, J., \& Mishra, S. (2016). Audio-visual aid in teaching "fatty liver". Biochemistry and molecular biology education : a bimonthly publication of the International Union of Biochemistry and Molecular Biology, 44(3), 241-245. https://doi.org/10.1002/bmb.20935

Dewi, P. Y., \& Primayana, K. H. (2019). Effect of learning module with setting contextual teaching and learning to increase the understanding of concepts. International Journal of Education and Learning, 1(1), 19-26. https://doi.org/10.31763/ijele.v1i1.26

Ferrari, P. L. (2003). Abstraction in Mathematics. Philosophical Transactions: Biological Sciences, 358(1435), 1225-1230. https://dx.doi.org/10.1098\%2Frstb.2003.1316

Freeman, S., Eddy, S. L., McDonough, M., Smith, M. K., Okoroafor, N., Jordt, H., \& Wenderoth, M. P. (2014). Active learning increases student performance in science, engineering, and mathematics. Proceedings of the National Academy of Sciences, 111(23), 8410-8416. https://doi.org/10.1073/pnas.1319030111

Guo, P., Kim, J., \& Rubin, R. (2014). How video production affects student engagement: An empirical study of MOOC videos. Association for Computing Machinery, 41-50. https://doi.org/10.1145/2556325.2566239

Hudson, C. C., \& Whisler, V. R. (2007). Contextual teaching and learning for practitioners. Journal of Systematics, Cybernetics and Informatics, 6(4). 54-58. https://doaj.org/article/bcea16a3e5564bd5b56707b6ba62d841

Ibrahim, M., Antonenko, P. P., \& Wheeler, D. (2012). Effects of segmenting, signalling, and weeding on learning from educational video. Learning, Media and Technology, 220-235. https://doi.org/10.1080/17439884.2011.585993

Killpatrick, J., Swafford, J., \& Findell, B. (2001). Adding It Up: Helping Children Learn Mathematics.

Mayer, R. E. (2009). Multimedia Learning. Yogyakarta: Pustaka Pelajar.

OECD. (2019). Is there a generational divide in environmental optimism? https://doi.org/10.1787/04677bea-en

Panduan Penilaian Oleh Pendidik dan Satuan Pendidikan Untuk Sekolah Menengah Atas. (2017). Direktorat Pembinaan SMA Ditjen Pendidikan Dasar dan Menengah.

Rusdi, M. (2018). Penelitian Desain dan Pengembangan Kependidikan. Depok: Rajawali Pers.

Saleh, H., \& Yumiati. (2019). NCTM's Principles and Standards for Developing Conceptual Understanding in Mathematics. Journal of Research in Mathematics Trends and Technology, 1(2), 52-60. https://doi.org/10.32734/jormtt.v1i2.2836

Schacter, D. L., \& Szpunar, K. K. (2015). Enhancing attention and memory during videorecorded lectures [doi:10.1037/st10000011]. US: Educational Publishing Foundation.

Schmid, R. F., Bernard, R. M., Borokhovski, E., Tamim, R. M., Abrami, P. C., Surkes, M. A., Woods, J. (2014). The effects of technology use in postsecondary education: A metaanalysis of classroom applications. Computers $\mathcal{E}$ Education, 72, 271-291. https://doi.org/10.1016/j.compedu.2013.11.002

Selvianiresa, D., \& Prabawanto, S. (2017). Contextual Teaching and Learning Approach of Mathematics in Primary Schools. Journal of Physics: Conference Series, 895, 012171. https://doi.org/10.1088/1742-6596/895/1/012171 
Stockwell, B. R., Stockwell, M. S., Cennamo, M., \& Jiang, E. (2015). Blended Learning Improves Science Education. Cell, 162(5), 933-936. https://doi.org/10.1016/j.cell.2015.08.009

Sugiyono. (2014). Metode Penelitian Kuantitatif, Kualitatif, dan RED. Bandung: Alfabeta.

Syamsuddin, S., \& Istiyono, E. (2018). The effectiveness of mathematics learning through contextual teaching and learning approach in Junior High School. AIP Conference Proceedings, 2014(1), 020085. https://doi.org/10.1063/1.5054489

Szpunar, K. K., Khan, N. Y., \& Schacter, D. L. (2013). Interpolated memory tests reduce mind wandering and improve learning of online lectures. Proceedings of the National Academy of Sciences, 110(16), 6313. https://doi.org/10.1073/pnas.1221764110

Xiao, L. (2013). Animation Trends in Education. Journal of Information and Education Technology, 3(3), 286-289. https://doi.org/10.7763/IJIET.2013.V3.282

Yavuzmumcu, H. (2018). Examining Mathematics Department Students' Views on the Use of Mathematics in Daily Life. International Online Journal of Education and Teaching, 5(1), 6180.

Yousef, A. M. F., Chatti, M., \& Schroeder, U. (2014). Video-Based Learning: A Critical Analysis of The Research Published in 2003-2013 and Future Visions. eLmL 2014 : The Sixth International Conference on Mobile, Hybrid, and On-line Learning, 112-119.

Zahra, S. B. (2016). Effect of Visual 3D Animation In Education. European Journal of Computer Science and Information Technology, 4(1), 1-9. 